\title{
Religious Studies
}

Books and Journals from Cambridge University Press

Cambridge has been publishing in the field of religious studies since 1584 , making our programme one of the oldest and most prestigious in the world.

We publish books and journals on a wide range of religions and topics, from church history and theology, to biblical studies and religious ethics.

Our publications represent the highest level of academic research from renowned authors. Series for students, including Cambridge Companions to Religion and Introductions to Religion, remain enduringly popular.

For further details visit: cambridge.org/core-religion

\section{Çambridge Core}




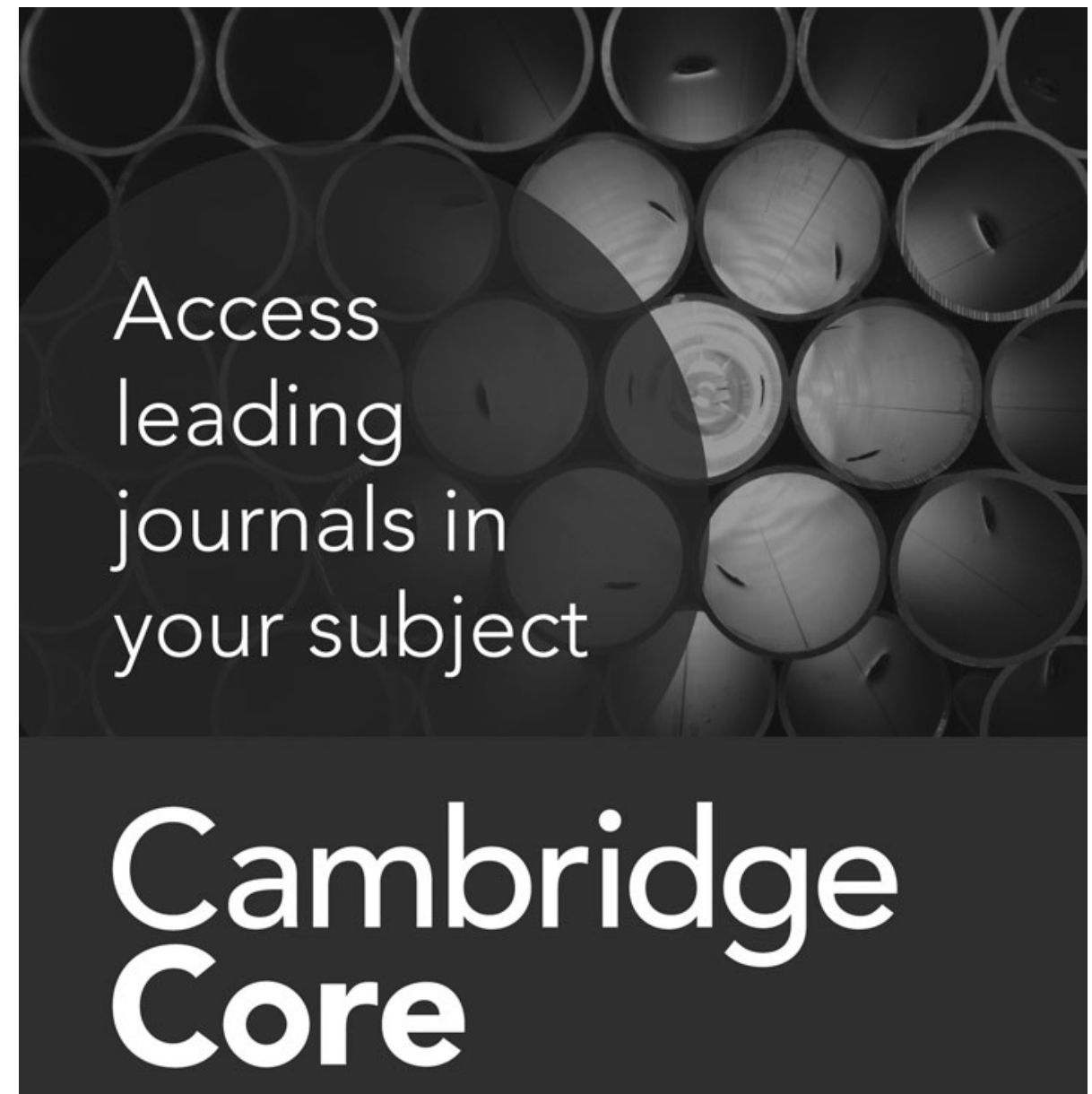

Explore today at cambridge.org/core

Cambridge Core 


\section{Religious Studies}

An international journal for the philosophy of religion

\section{Editorial policy}

Religious Studies is an international journal devoted to the problems of the philosophy of religion as these arise out of classical and contemporary discussions and from varied religious traditions. Space is devoted to articles, of which more than 25 are published each year, but the journal also contains a book review section, which may include review articles and shorter notes as well as normal-length reviews.

\section{Submissions}

All contributions must be submitted via the electronic submission system at http://mc.manuscriptcentral.com/rst

For further details, please visit the journal's website: cambridge.org/res

No article will be accepted for publication without blind review. The text of submitted articles must be ready for this and must bear no trace of the author's identity. Articles that are not ready for blind review will be rejected. Discussion notes should be replies to papers published in Religious Studies.

Submission of a paper will be taken to imply that it is unpublished and is not being considered for publication elsewhere. Upon acceptance of a paper, the author will be asked to assign copyright (on certain conditions) to Cambridge University Press.

Contributors are responsible for obtaining permission to reproduce any material in which they do not hold copyright and for ensuring that the appropriate acknowledgements are included in their manuscript.

Books for review should be sent to Dr Clare Carlisle at Department of Theology and Religious Studies, King's College London, Strand, London WC2R 2LS.

Books not selected for review will not be returned.

NB: Religious Studies does not accept unsolicited book reviews.

\section{Manuscript preparation}

Articles must be submitted as Word files to the journal and should not be more than 8,000 words long. Articles in two or more parts may occasionally be accepted provided each part is independently intelligible. They should be in English.

Each article must be submitted with an abstract of 100 words.

When an article has been accepted for publication, the author must prepare their manuscript according to the journal style guide which can be found at www.journals.cambridge.org/res Articles and book reviews will be checked and copy-edited for journal style and UK English.

The manuscript must be supplied in electronic format as Microsoft Word accompanied by a pdf of the same file.

\section{Proofs}

First proofs are sent to contributors by e-mail as PDF files. Corrections will only be accepted if they are returned within the specified time.

Typographical or factual errors only may be changed at proof stage. The publisher reserves the right to charge authors for correction of non-typographical errors.

\section{Offprints}

Complimentary offprints are not supplied. Each Author will receive a pdf file containing their contribution to the journal, for their own use. Authors of Articles will also receive a copy of the journal.

(C) Cambridge University Press 2017

CAMBRIDGE UNIVERSITY PRESS

University Printing House, Shaftesbury Road, Cambridge св2 8BS, United Kingdom

1 Liberty Plaza, Floor 20, New York, NY 10006, USA.

477 Williamstown Road, Port Melbourne, vIC 3207, Australia Ruiz de Alarcón 13, 28014 Madrid, Spain

Dock House, The Waterfront, Cape Town 80o1, South Africa

Printed in the UK by Bell \& Bain Ltd, Glasgow. 


\section{Religious
Studies}

\section{ARTICLES}

WILLIAM HASKER

A compositional incarnation [433]

ANDREW M. BAILEY

On the concept of a spirit [449]

PAUL K. MOSER

How not to defend Positive Evidential

Atheism [459]

\section{ERIK BALDWIN}

Why Islamic 'Traditionalists' and 'Rationalists' both ought to accept Rational Objectivism

[467]

\section{VICTORIA S. HARRISON}

Mathematical objects and the object of

theology [479]

JAMES E. GILMAN

The metaphysics of belief: a Wittgenstein and Collingwood convergence [497]

\section{MICHAEL BARNWELL}

The 'harder problem' of the devil's fall is still a problem: a reply to Wood [521]

\section{BOOK SYMPOSIUM}

MARK C. MURPHY

Précis of God's Own Ethics [545]

ERIK J. WIELENBERG

Intrinsic value and love: three challenges

for God's Own Ethics [551]

\section{KRISTEN IRWIN}

Enabling Ivan Karamazov: responding to Mark Murphy's God's Own Ethics: Norms of Divine Agency and the Argument from Evil [557]

\section{PAUL DRAPER}

Evil and the God of Abraham, Anselm, and Murphy [564]

MARK C. MURPHY

Replies to Wielenberg, Irwin, and Draper [572]

\section{BOOK REVIEW}

SCOTT A. DAVISON

Petitionary Prayer: A Philosophical Investigation (Vincent Brümmer) [585]

\section{Cambridge Core}

For further information about this journal

please go to the journal web site at

cambridge.org/res

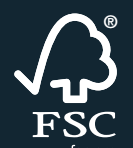

www.fsc.org
MIX

Paper from responsible sources FSC $^{\ominus}$ C007785
CAMBRIDGE
UNIVERSITY PRESS 